\section{Acknowledgments}

We wish to thank Dr L. Henry, Consultant Pathologist, for his help and advice, the Photography Department for the illustration, Dr J. K. Barkla, Leader, Biomedical Information Project, University of Sheffield, for helping in a search of the literature aided by UK Medlars, and Mr D. $H$. Randall, Consultant Surgeon, Royal Infirmary, and Professor H. L. Duthie, Professor of Surgery, for their advice.

\section{References}

Al-Bahrani, S.R. \& BakiR, F. (1971) Primary intestinal lymphoma. A challenging problem in abdominal pain. Annals of the Royal College of Surgeons, 49, 103.

Balikian, J.P., Nassar, N.T., Shamma'a, M.H. \& Shahid, K.J. (1969) Primary lymphomas of the small intestine including the duodenum. A roentgen analysis of 29 cases. American Journal of Roentgenology, 197, 131.
Dawson, I.M.P., CoRnes, J.S. \& Morson, B.C. (1961) Primary malignant lymphoid tumours of the intestinal tract. Report of 37 cases with a study of factors influencing prognosis. British Journal of Surgery, 49, 80.

Ehrlich, A.N., Stalder, G., Geller, W. \& Sherlock, P. (1968) Gastrointestinal manifestations of malignant lymphoma. Gastroenterology, 54, 1115.

Pimparkar, B.D. (1964) Gastroenterology (Ed. by Henry L. Bockus), Volume II, p. 138. W. B. Saunders and Company: Philadelphia and London.

Portmann, U.V., Dunne, E.F. \& Hazard, J.B. (1954) Manifestations of Hodgkin's disease of the gastrointestinal tract. American Journal of Roentgenology, Radiotherapy and Nuclear Medicine, 72, 772.

WhitMORE, W.H. (1948) Duodenal diverticula with ulceration. American Journal of Roentgenology, Radiotherapy and Nuclear Medicine, 59, 343.

\title{
Thioridazine-induced diarrhoea
}

\author{
A. B. S. Mitchell \\ M.B., M.R.C.P. \\ Department of Gastroenterology, Charing Cross Hospital, London
}

\section{Summary}

Treatment for hypertension in a 68-year-old woman led to anxiety and depression which, in their turn, were successfully treated with thioridazine. Subsequent diarrhoea was shown to have been a side effect of this tranquillizer.

\section{Introduction}

Drugs based on the phenothiazine nucleus are frequently used for their psychotropic effects. Constipation is a common unwanted effect on bowel function (Kinross-Wright, 1955; Lomas, Boardman and Markowe, 1955; Hollister, 1961; Martindale, The Extra Pharmacopoeia, 1972; Shepard, Lader and Lader, 1972). Diarrhoea is mentioned in Martindale, The Extra Pharmacopoeia (1972) as an occasional complication of such therapy, but no references are cited, and the cases reported by Grahmann (1967) had complex additional symptomatology.

Diarrhoea has not previously been reported as a complication of thioridazine ('Melleril') therapy. In the following case this coincidence was such as to suggest a causal relationship.

Correspondence: Dr A. B. S. Mitchell, Consultant Physician, Prince of Wales Hospital, London N15 4AN.

\section{Case report}

A 68-year-old housewife had been under medical care for 6 years and been treated for labile, predominantly systolic hypertension. Her symptoms during this time were those of anxiety and depression,

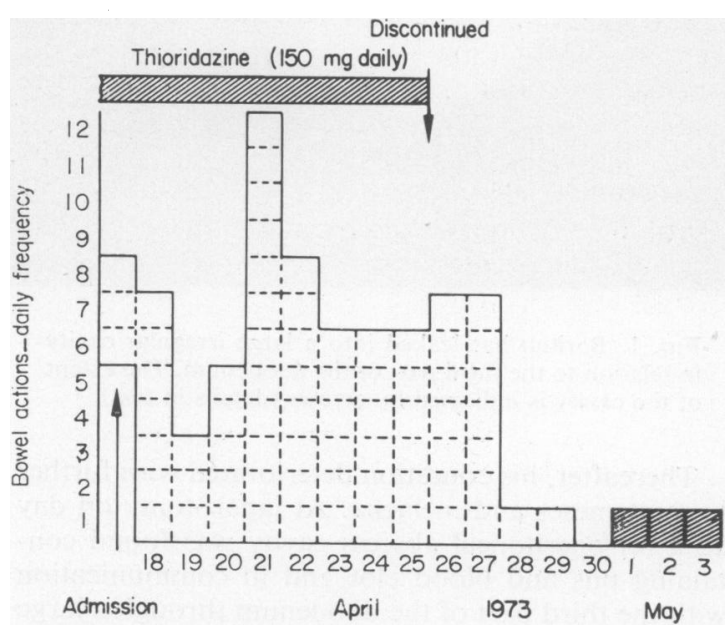

Fig. 1. Frequency and consistency of bowel actions related to drug exposure. Liquid, $\square$; formed, 
and those possibly related to antihypertensive drug therapy. This was discontinued in May 1972. Various psychotropic drugs (fluphenazine hydrochloride with nortriptyline hydrochloride, trifluoperazine, amylobarbitone sodium) failed to improve her mental state and in January 1973 she was admitted to a psychiatric ward. A depressive state with endogenous features and a possible reactive element was diagnosed. Despite psychotherapy, together with iprindole and chlordiazepoxide for the first month, improvement failed to occur.

On 5 March 1973, thioridazine ('Melleril') $150 \mathrm{mg}$ daily was prescribed, and she improved so that she was discharged from hospital on 14 March. Diarrhoea started on 1 April. Diphenoxylate tablets, six daily, did not control this, and she was referred to the gastroenterological clinic on 13 April. On examination the only abnormal physical findings in this anxious patient were excoriation of the perianal skin and the absence of submucosal vasculature on sigmoidoscopic inspection of the rectal mucosa. This was not friable. She was euthyroid. Codeine phosphate $360 \mathrm{mg}$ daily was prescribed.

There had been no improvement by the time she was next seen on 17 April. Plasma potassium was $2.5 \mathrm{mEq} / \mathrm{l}$. Other plasma electrolytes and urea, serum calcium and liver function tests were normal. No salmonellae nor shigellae had been grown in culture of her faeces, nor were parasites, ova or cysts observed. Histology of a rectal mucosal biopsy specimen showed Paneth cell metaplasia and infiltration of the lamina propria by eosinophils. White blood cell count was $7300 / \mathrm{mm}^{3}$, with no eosinophilia. Haemoglobin concentration was $13.4 \mathrm{~g} / 100 \mathrm{ml}$ and ESR was $6 \mathrm{~mm}$ in the first hour (Westergren).

Diarrhoea was confirmed, and the daily frequency, which varied from 3 to 12 (mean 6.7), was unaffected by Kaolin and Morphine Mixture $40 \mathrm{ml}$ daily (chart). No abnormalities were found on barium enema and barium meal and follow-through examinations. Hypokalaemia was corrected by oral potassium chloride supplements to her diet (repeat plasma potassium levels were 4.1 and $4.4 \mathrm{mEq} / \mathrm{l})$. On 25 April thioridazine was discontinued. On both 26 and 27 April she passed seven liquid bowel actions. On the 28 and 29 April the faecal consistency was unchanged but the frequency was reduced to a single bowel action. Since then formed stools have been passed daily.

Her psychiatric state is being managed by supportive psychotherapy.

\section{Discussion}

The phenothiazine group of drugs have both an adrenergic blocking action and an anticholinergic effect (Hollister, 1961). The latter is dominant. Constipation can, therefore, be anticipated as an effect on bowel function, but not diarrhoea. Experience with chlorpromazine, an aliphatic derivative of the phenothiazine group, certainly supports this hypothesis.

The patient received two other drugs of the phenothiazine group, both piperazine derivatives, flufenazine and trifluoperazine. No effect on bowel function was noted.

Four weeks after starting a course of thioridazine (a piperidine derivative of the phenothiazine group) diarrhoea began and continued with sufficient severity to result in hypokalaemia and perianal excoriation. Because diarrhoea had not been described as complicating therapy with thioridazine, nor was it to be expected from its pharmacological actions, and because it had been difficult to ameliorate this patient's psychopathology, the drug was continued while investigations excluded other causes. Within 3 days of stopping the drug the frequency of bowel actions had returned to normal, and within 5 days the consistency of the faeces was normal. This suggests that the diarrhoea in this patient resulted from an idiosyncratic reaction to the pharmacological properties of thioridazine.

Confirmation of this conclusion might have been provided by re-exposure of the patient to the suspected offending drug. This was not considered justifiable in a psychologically disturbed patient.

\section{Acknowledgments}

I should like to thank Dr Marion Woolaston for referring the patient, and Dr A. Morton Gill under whose care the patient was admitted. Mr Anthony Rollason kindly designed and prepared the chart.

\section{References}

Grahmann, H. (1967) Mittelüberdeuernde Nebenwirkungen nach langfristiger behandlung mit psychopharmaka. Naunyn-Schmiedeberg's Archiv für experimentelle Pathologie u. Pharmakologie, 257, 23.

Hollister, L.E. (1961) Complications from psychoptherapeutic drugs 1. New England Journal of Medicine, 264, 291.

KINROSS-WRIGHT, V. (1955) Complieations of chlorpromazine treatment. Disease of the Nervous System, 16, 114.

Lomas, J., Boardman, R.H. \& Markowe, M. (1955) Complications of chlorpromazine therapy in 800 mental hospital patients. Lancet, i, 1144.

Martindale, The Extra Pharmacopoeia. (1972). Twentysixth edition (Ed. by N. W. Blacow), p. 1812. The Pharmaceutical Press, London.

ShePPARd, M., LADER, M. \& LAder, S. (1972) Phenothiazine Derivatives, Major Tranquillizers. In: Side Effects of Drugs (Ed. by L. Meyer and A. Herxheimer), vol. 7, p. 71 Excerpta Medica: Amsterdam. 